\title{
AGRICULTURAL EXTENSION SERVICE IN SERBIA - ATTITUDES OF FARMERS
}

\author{
Marija Nikolić ${ }^{1}$ \\ Tamara Paunović ${ }^{2}$ \\ Milena B. Stevović ${ }^{3}$
}

DOI: https://doi.org/10.31410/LIMEN.2020.389

\begin{abstract}
In modern agriculture, farmers face certain problems in obtaining necessary information and improving agricultural production. This paper aimed to reveal the standpoints of farmers related to the role of agricultural extension services (AES) as a source of information and farmers' opinion on the quality of work of extension officers. In order to examine this goal, two municipalities were selected, Alibunar and Kruševac. A total of 65 farmers were included in the research and a survey of their attitudes was conducted.

The analysis of farmers' attitudes indicates that some of them are still not sufficiently familiar with the work of extension service. In the municipality of Alibunar, the most important source of information is other farmers, although half of them regularly use services of AES. Farmers in Kruševac are more focused on using the services of extension officers, which they value as the most important source of information related to agricultural production. Farmers from both municipalities think that the work of extension officers, both in terms of transparency and quality of information, can be improved.
\end{abstract}

Keywords: Standpoints, Farmers, Extension service, Improving the quality of work.

\section{INTRODUCTION}

$\mathrm{S}$ ignificant changes in the global market have greatly affected agricultural production. The demands placed on today's farmers include not only the production of sufficient quantities of safe food, but also the application of modern measures and numerous innovations in the production process. The success of this process depends primarily on the characteristics of the farmers: their level of education, readiness to attend additional educational seminars, commitment to lifelong learning, but also openness to change and willingness to minimize the impact of tradition on the business decision-making process. An important factor that should facilitate this process and help farmers to improve agricultural production is agricultural extension service.

The most important provider of agricultural extension services in Serbia, as in most SouthEastern European countries, is public agricultural extension service (PAES). The availability of modern extension services to agricultural producers and small businesses is extremely important for the development of agriculture (Volk et al., 2015). The efficiency of the extension service depends on the ability and competence of the extension officers, but also on their focus on the needs and requirements of service users, mostly agricultural producers. That is why

Faculty of Agriculture, University of Belgrade, Nemanjina 6, 11080 Belgrade, Serbia Faculty of Agriculture, University of Belgrade, Nemanjina 6, 11080 Belgrade, Serbia Faculty of Agriculture, University of Belgrade, Nemanjina 6, 11080 Belgrade, Serbia 
understanding the attitudes of farmers towards the work of PAES are of vital importance for the work of the service itself.

The effectiveness of extension services is highly dependent on the quality of work of extension officers, which is evaluated based on the degree of their clients' satisfaction. Therefore, the function of extension service should be created on the basis of information on attitudes of farmers towards AES, otherwise it will not be viable (Qtaishat \& AL-Sharafat, 2012). The paper aims to reveal the attitudes of farmers regarding the role of agricultural extension services as a source of such information and their opinion on the quality of work of extension officers in selected municipalities in Serbia.

\section{MATERIALS AND METHODS}

The research presented in this paper is aimed at examining the attitudes of farmers from the two municipalities towards the work of the agricultural extension service. Two types of data are used in research: primary data collected through the survey and secondary data obtained from relevant research by domestic and foreign authors. Primary data were collected in June and July 2020, using the face-to-face survey technique, based on a pre-prepared questionnaire. A total of 65 respondents were interviewed, of which 35 from the municipality of Alibunar and 30 from the municipality of Kruševac. The data were processed in SPSS 19.0, using descriptive statistics, Independent Samples t-Test for comparison of data from selected municipalities and Pearson's linear correlation coefficient to determine the correlation between individual variables.

In order to perceive the characteristics of municipalities and to justify their selection, the data from the Statistical Office of the Republic of Serbia, namely Census of Agriculture 2012 and Farm Structure Survey 2018 were used. The aim was to select two municipalities that differ in agrarian structure and characteristics of farm managers. Two municipalities were selected Alibunar from the Autonomous Province of Vojvodina and the municipality of Kruševac from Central Serbia. These municipalities differ greatly in the observed characteristics, which contributes to the quality of the research.

\section{Characteristics of municipalities included in the research}

According to Farm Structure Survey 2018 (SORS), there are 3,013 farms in the municipality of Alibunar, representing $0.5 \%$ of the total number of farm in the Republic of Serbia. Comparing to Census of Agriculture 2012, the number of farm decreased by 407 or $11.9 \%$, which is, in percentages, more than in the Republic of Serbia (10.6\%). Farms with more than 5 ha of agricultural land participate with $49.6 \%$ in the total number of farms and occupy $95.3 \%$ of the utilised agricultural land. Farms between 10 and 50 hectares in size are the most numerous (921 or $30.6 \%$ ).

In the municipality of Kruševac, in 2018 there were 11,867 farms or $2.1 \%$ of the total number of farms in the Republic of Serbia. Compared to 2012, the number of farms decreased by 797 or $6.3 \%$, which indicates a slower decrease compared to the national level. Farms with up to 5 ha of agricultural land represent $88.3 \%$ of the total number of farms, while larger farms $(>50$ ha) are less represented.

Out of 564.541 farms in Serbia (2018), managers of $95.3 \%$ of them have only practical experience, and only $1.29 \%$ of managers have higher training. In the municipality of Alibunar, 
$91.0 \%$ of managers have only practical experience, and $35(1.16 \%)$ have additional training, of which most (15 or 42.9\%) are from farms ranging in size from 5 to 10 ha. In Kruševac, even $96.3 \%$ of managers have only practical experience, which is above the national average, while 93 of them $(0.78 \%)$ have higher training. As in the municipality of Alibunar, most managers with training are from farms that have 5 to 10 ha of agricultural land.

The provision of extension services by the public extension service on the territory of Alibunar is conducted by the AES Institute Tamiš Pančevo, and on the territory of the municipality of Kruševac by the Agricultural Extension and Advisory Service Kruševac.

\section{RESULTS AND DISCUSSION}

\section{Socio-demographic characteristics of the respondents}

The research included a total of 65 respondents, namely agricultural producers $-35(53.8 \%)$ from the municipality of Alibunar and $30(46.2 \%)$ from the municipality of Kruševac. There are significantly more males (60 or $92.3 \%$ ) than females ( 5 or $7.7 \%$ ) in the sample, which is to be expected since the intention was to include farm holders in the research. The average age of the respondents was 49, with the standard deviation being high (11.578), since the respondents were from 22 to 72 ages. Independent Samples t-Test showed that there is no statistically significant difference between the average age of respondents from the observed municipalities (for the municipality of Alibunar $\mathrm{M}=49.77 ; \mathrm{SD}=12.010$ and for the municipality of Kruševac $\mathrm{M}=48.30 ; \mathrm{SD}=11.204 ; \mathrm{t}=0,508 ; \mathrm{p}=0.613)$. According to the level of education, most respondents are with high school -53 or $81.5 \%$, while an equal number of respondents are with primary school and university degree (6 or 9.2\%). All 6 respondents with university degree are from the municipality of Alibunar.

For 42 respondents $(64.6 \%)$ agriculture is the primary occupation, with more respondents from the municipality of Kruševac giving this answer $(21$ or $70.0 \%$ of the number of respondents from this municipality) compared to the municipality of Alibunar (21 or 60.0\%). The research included farmers who have been engaged in agriculture from 2 to 50 years, with the average experience in agricultural production being 20.8 years. There is no significant difference between the length of engagement in agricultural production in the two observed municipalities (based on the results of the Independent Samples t-Test).

Only five respondents (7.7\%) are engaged in animal husbandry. Most of them are engaged in growing of cereal (37 or $56.9 \%$ ), followed by growing fruit (12 or $18.5 \%$ ), vegetable (9 or $13.8 \%$ ), and finally viticulture (two or $3.1 \%$ ). All respondents whose dominant production is growing vegetables are from the municipality of Kruševac, while fruit growing is similarly represented in the municipality of Alibunar (five respondents) and the municipality of Kruševac (seven respondents). The average mark of the intensity of agricultural production (evaluated by farmers) on farms is 3.88. There are no significant differences between the municipalities in terms of the estimated intensity of agriculture (Alibunar $\mathrm{M}=3.97 ; \mathrm{SD}=0.747$ and Kruševac $\mathrm{M}=3.77 ; \mathrm{SD}=0.858$ ), while none of the farmers assessed their production as completely non-intensive (score one on a five-point Likert scale).

\section{The level of farmers' awareness of innovations in agriculture}

The surveyed farmers assessed their own level of information related to innovations in agricultural production, also on a five-point scale. The average assessment of respondents in 
both municipalities is 3.20. Using the Independent Samples t-Test, it was found that there is a significant difference between the information level of farmers in municipalities: farmers in the municipality of Alibunar believe that they are more informed $(\mathrm{M}=3.57, \mathrm{SD}=1.01)$ compared to farmers from the municipality of Kruševac $(M=2.77, S D=1.19 ; t=2.871$; $\mathrm{p}=0,006)$.

Modern agricultural production is based on the application of new knowledge and information, not only in order for farmers to achieve their own goals, but also to realize national goals aimed at producing a sufficient amount of food (Čikić and Petrović, 2013). The classical linear model of innovation and knowledge transfer in modern agriculture is being replaced by an interactive and networking model (Nikolić and Paunović, 2019; Zrakić et al., 2018). Farmers need to be innovative, able to tackle problems and responsive to new opportunities (Nikolić and Paunović, 2019). In order to do so, farmers need different types of information. Today, farmers have access to abundance of information from various sources, which imposes to them the need to be able to evaluate and select the information they really need. This process requires certain knowledge from farmers, who must assess the credibility, objectivity and reliability of existing information because only such information can be a good basis for making the right decision. The role of AES in this process remains crucial. For these reasons, it was analysed to what extent the surveyed farmers see AES as a source of valid information.

The surveyed farmers from both municipalities assessed the agricultural extension service as an extremely important source of information. If the average grade of all respondents is observed, AES was rated with the highest mark (3.94) (Graph 1). It is interesting that the farmers from Kruševac rated higher than the farmers from Alibunar only the information provided by experts employed in AES and agricultural pharmacies. In other words, farmers in the municipality of Kruševac have more confidence in the information they receive from the experts employed in institutions, compared to information from other sources. The obtained results are in line with previous research in which it was found that half of farmers consider AES as a source of valid information (Sarker \& Itohara, 2009).

Figure 1. The Average score for selected sources of information obtained by respondents

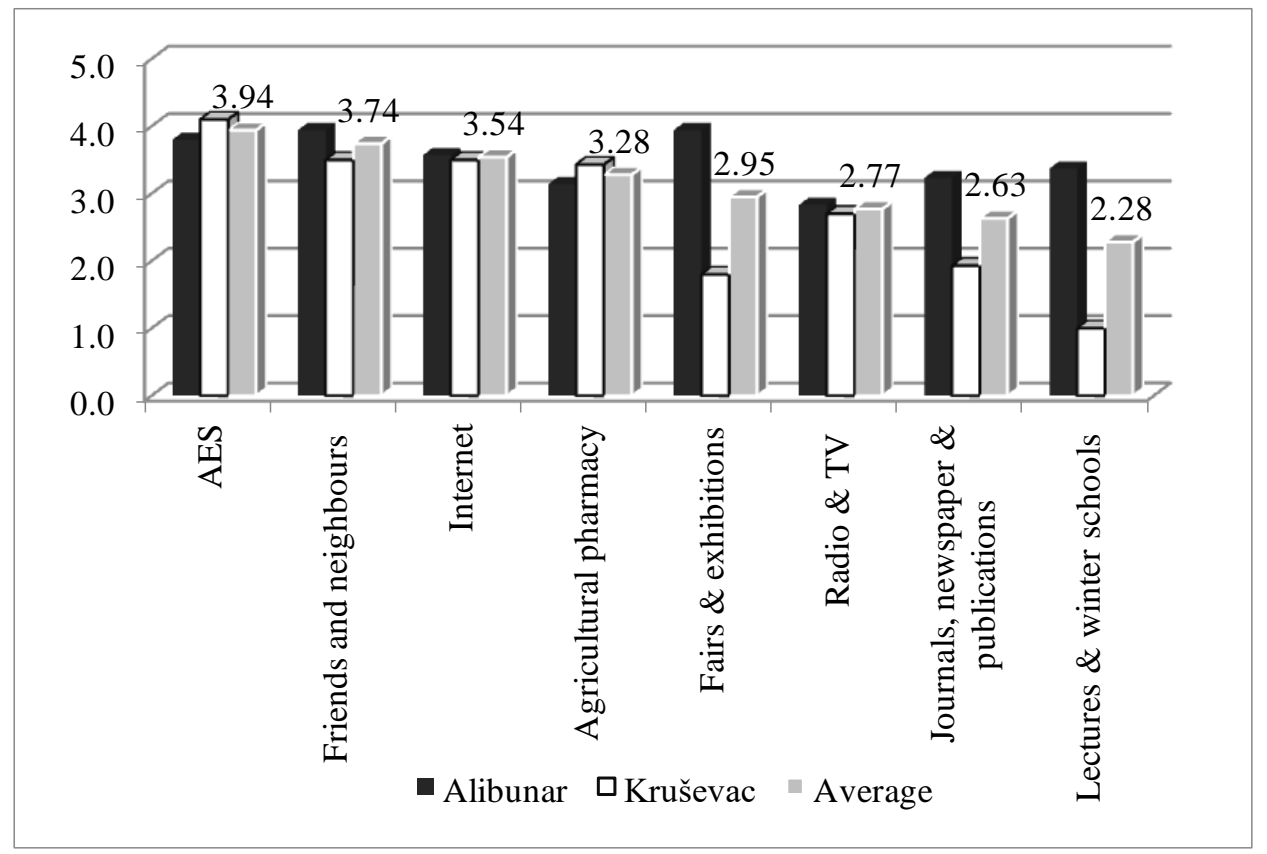

Source: Authors' calculation based on data from research 
Farmers from Alibunar rated their own awareness of innovations in agricultural production with a higher average score (3.57) compared to farmers from Kruševac (2.77). This can be related to the following results, according to which farmers from the municipality of Alibunar perceive friends and neighbours (average score 3.94), fairs and exhibitions (3.94), and even the Internet (3.57) as important sources, i.e. they high evaluate those sources that allow them to independently collect and evaluate information. At the same time, farmers from the municipality of Kruševac rated fairs and exhibitions as the second least important source of information (score 1.80; after lectures and winter schools, which were rated the lowest - 1.00). This is consistent with other research which also confirmed that farmers perceive fairs, demonstrations and exhibitions as an insignificant source of information (Al-Zahrani et al., 2016). Farmers from both municipalities, on average, rated the worst sources of information that include the use of mass media, namely radio and TV programs, magazines, newspapers and other forms of print media, but also lectures and winter schools.

Special attention in the research is paid to cooperation and attitudes of farmers about the quality of cooperation with the agricultural extension service. In that sense, first of all, it was necessary to examine the extent to which the surveyed farmers cooperate with AES. Regular contacts between extension officers and farmers contribute to the quality of extension services, because in this way two-way communication is achieved, which also contributes to strengthening the perception of farmers that AES is a source of reliable information (Sarker \& Itohara, 2009; Qtaishat \& AL-Sharafat, 2012). At the same time, irregular visits by extension officers result in farmers' dissatisfaction with the work of this service (Maoba, 2016).

More respondents from the municipality of Kruševac cooperate with extension officers ( 21 or $70.0 \%$ ) compared to the municipality of Alibunar (19 or $54.3 \%$ where three of these respondents stated that the extension officers initiated cooperation, compared to the remaining 16 who independently sought the help of AES). Farmers from the municipality of Alibunar more often cooperate with extension officers, four (11.4\%) on a monthly basis, and five $(14.3 \%)$ several times a year (Table 1$)$.

Table 1. Frequency of farmers' contacts with AES

\begin{tabular}{|c|c|c|c|c|c|c|}
\hline & \multicolumn{2}{|c|}{ Alibunar } & \multicolumn{2}{|c|}{ Kruševac } & \multicolumn{2}{|c|}{ Total } \\
\hline & Number & Percent & Number & Percent & Number & Percent \\
\hline Once a month & 4 & 11,4 & 0 & - & 4 & 6,2 \\
\hline $\begin{array}{l}\text { Several times per } \\
\text { year }\end{array}$ & 5 & 14,3 & 6 & 20,0 & 11 & 16,9 \\
\hline Once a year & 7 & 20,0 & 15 & 50,0 & 22 & 33,8 \\
\hline $\begin{array}{l}\text { Once in several } \\
\text { years }\end{array}$ & 3 & 8,6 & 0 & & 3 & 4,6 \\
\hline $\begin{array}{l}\text { Total number of } \\
\text { farmers that have } \\
\text { contact with AES }\end{array}$ & 19 & 54,3 & 21 & 70,0 & 40 & 61,5 \\
\hline Never & 16 & 45,7 & 9 & 30,0 & 25 & 38,5 \\
\hline \multicolumn{5}{|c|}{ Total in both municipalities } & 65 & 100,0 \\
\hline
\end{tabular}

Source: Authors' calculation based on data from research

Interestingly, there are no particular features that distinguish these farmers from others: the average age and length of engagement in agricultural production is at the level of the entire sample, five stated that agriculture is not their primary occupation; two are university educated, while others are with high school education. The only difference is reflected in the average size 
of arable land: at the level of the municipality of Alibunar the average size of land per respondent is 93.8 ha, while among respondents who have regular contact with AES is 108.1 ha. However, it should be noted that five out of the 11 respondents $(45.5 \%)$ who cultivate over 100 ha in the municipality of Alibunar stated that they never use the services of AES. It does not mean that they do not have access to extension services, since these farmers highly valued other sources of information, and one of them also hires a private advisor.

Farmers who had contact with AES representatives expressed their views on the quality of work of agricultural extension officers. These assessments are grouped into three categories: the importance and quality of information provided by AES, the cooperation of AES with farmers and the quality of this cooperation (Table 2).

Farmers from both municipalities believe that they receive enough reliable and quality information from AES. Despite that, farmers from Kruševac believe that the information is repeated from year to year. These respondents rated with a score 3.57 the attitude that the obtained information helps them in running and improving the farm, which, in addition to the previous attitude, indicates that they are not completely satisfied with the obtained information. Farmers in the municipality of Alibunar believe that AES renew the information it provides on an annual basis, but they gave lower marks to their impartiality. As these farmers are focused (to a greater extent) on other sources of information, and not only on AES, it means that they tend to compare the obtained information from different sources and only then make decisions. This imposes greater demands on extension officers who provide services in the municipality of Alibunar.

Table 2. Respondents' attitude towards the work of AESs in Serbia

\begin{tabular}{|c|c|c|c|}
\hline & Alibunar & Kruševac & Total \\
\hline \multicolumn{4}{|c|}{ Significance and quality of information provided by AES } \\
\hline They provide information on agricultural production & 4,26 & 4,86 & 4,58 \\
\hline They provide information on financial resources & 3,58 & 3,10 & 3,33 \\
\hline AES provides unbiased information & 3,32 & 4,33 & 3,85 \\
\hline The information is reliable and can be trusted & 4,26 & 4,05 & 4,15 \\
\hline $\begin{array}{l}\text { The information provided by AES is of practical } \\
\text { importance for the improvement of the farm }\end{array}$ & 4,05 & 3,57 & 3,93 \\
\hline $\begin{array}{l}\text { The information provided by AES is the same every } \\
\text { year }\end{array}$ & 2,58 & 4,33 & 4,58 \\
\hline \multicolumn{4}{|l|}{ Cooperation of AES with farmers } \\
\hline They show new ways of doing business & 4,26 & 3,57 & 3,90 \\
\hline They help farmers acquire new knowledge & 4,26 & 4,10 & 4,18 \\
\hline They help farmers make decisions & 3,84 & 4,52 & 4,20 \\
\hline They help farmers analyse their own problems & 3,42 & 2,62 & 3,00 \\
\hline \multicolumn{4}{|l|}{ Quality of cooperation } \\
\hline It is easy to get in touch with AES & 4,42 & 4,71 & 4,58 \\
\hline $\begin{array}{l}\text { Extension officers cooperate equally with all } \\
\text { farmers }\end{array}$ & 3,63 & 3,14 & 3,38 \\
\hline They pay enough attention to farmers & 3,79 & 4,05 & 3,93 \\
\hline $\begin{array}{l}\text { AES informs farmers through newspapers, radio and } \\
\text { television about important news related to } \\
\text { agricultural production }\end{array}$ & 3,74 & 1,05 & 2,33 \\
\hline
\end{tabular}

Source: Authors' calculation based on data from research 
With the lowest average score the respondents evaluated the information they receive from AES which refer to the sources of financing of agricultural production. This indicates the need for continuous education of extension officers, especially from the segment of existing support that farmers can use from the relevant ministry and local government. At the same time, this may indicate that farmers have poor access to finance (Veselinović and Drobnjaković, 2014).

Farmers in Kruševac rely more on the services of AES in decision-making, but they evaluated the work of extension officers less in terms of demonstrating new technical knowledge (ways of doing business) and the support they receive in analysing their own problems. Although the obtained mean score can be evaluated as average (3.00), it should be noted that according to other research, the willingness of extension officers to help farmers identify their problems and solve them is rated very low (1.9 on a scale of 1 to 5 ) and that it represents one of the biggest challenges facing modern AES (Maoba, 2016).

The surveyed farmers also showed a high degree of agreement with the attitudes that it is easy to get in touch with AES, i.e. that extension officers pay enough attention to them. Respondents again expressed the view that the mass media are insufficiently used in the work of the AES, especially in the municipality of Kruševac. The application of mass media in extension work is of particular importance because it enables coverage of a large number of users in a relatively short period at low costs. In recent years, there has been a change in the type of mass media used in extension work. Print media (pamphlets, reports, flyers) predominantly used by public AES is being increasingly replaced by electronic media (Norton \& Alwang, 2020). That is why continuous education of extension officers is imperative in organizing a modern and efficient AES.

Finally, respondents who cooperated with AES assessed the degree of satisfaction with the cooperation with this service, which is crucial for understanding their attitudes towards the quality of extension services provided. The average score of all respondents is high and amounts to 4.08 , with a higher degree of satisfaction shown by respondents from the municipality of Alibunar (4.32) compared to Kruševac (3.86). This is consistent with previous surveys of the level of user satisfaction with AES services, when it was found that $67 \%$ of respondents rated the quality of extension services as the highest, while $33 \%$ as satisfactory (Đurić et al., 2019).

Using Pearson's linear correlation coefficient, it was determined that there is no statistically significant relationship between the assessment of respondents' satisfaction with AES work and their age $(\mathrm{r}=-0.173 ; \mathrm{Sig}=0.287 ; \mathrm{N}=40)$, and education level $(\mathrm{r}=0.096 ; \mathrm{Sig}=0.556 ; \mathrm{N}=40)$. This is in contrast to other studies in which it has been found that farmers with a higher level of education have more positive attitude towards AES (Qtaishat \& AL-Sharafat, 2012). However, a medium-strong negative correlation was determined between the degree of satisfaction of AES service and the length of farmers' engagement in agriculture $(\mathrm{r}=0.465$, $\mathrm{N}=40$, at the level of significance 0.01 ), where respondents with less experience in agricultural production showed a higher degree of satisfaction with the work of agricultural extension officers. This can be confirmed in other research where was found that younger farmers with less experience show more tendency to try and adopt innovation in production process (Idrisa \& Ogunbameru, 2008). The coefficient of determination is $21.6 \%$, which means that more than $20 \%$ of the users' satisfaction with extension services depends upon how long the respondents have been engaged in agricultural production. 


\section{FUTURE RESEARCH DIRECTIONS}

The particularity of extension work in agriculture is reflected in the fact that it is difficult to quantify its effects. That is why considering the degree of customer satisfaction with the services provided is a starting point that can be used to evaluate the success of AES. The conducted research indicates that there is a certain degree of user satisfaction with the work of agricultural extension officers, but also that there are significant differences in the perception of the quality of services received by farmers from the two municipalities covered by the research. Future research should be more comprehensive both in terms of geography and the number of respondents included in the research, in order to obtain more detail results.

\section{CONCLUSION}

In the paper are presented the results of a research related to the assessment of the attitudes of farmers from two municipalities, Alibunar and Kruševac, towards the work of agricultural extension officers. A total of 65 respondents were interviewed. As the primary objective of AES was to provide new knowledge and information to farmers; it was examined to what extent farmers are informed, as well as from which sources they obtain information. The average score of respondents' awareness is 3.20 on a five-point scale, with significant differences between the observed municipalities, in favour of farmers from Alibunar. The most important source of information is AES, especially for farmers from the municipality of Kruševac, while producers from the municipality of Alibunar also obtain information from friends and neighbours, at fairs and exhibitions and from the Internet.

Out of 65 farmers, 40 have contacts with representatives of the public AES. Although the respondents expressed the opinion that they receive enough information from extension officers, they evaluated less the importance of these information for improving the work of their farm, impartiality of information, as well as the readiness of extension officers to cooperate equally with all interested farmers. This indicates that although there are contacts between extension officers and users of their services; there is a need to suit the type and structure of information, as well as communication channels, to the needs and expectations of farmers.

Finally, farmers cooperating with AES rated the quality of that cooperation with an average score of 4.08. It is interesting to note that there is a statistically significant relationship between the length of engaging in agricultural production and the degree of satisfaction with the work of AES, whereby respondents who have less experience in agriculture showed a higher degree of trust in agricultural extension officers. This can be explained by the fact that respondents who have been engaged in agricultural production recently need more help from extension officers, but also the readiness of this group of producers to put innovations in use, i.e. to deviate from traditional models and techniques of farming.

The obtained results show that there are established channels of communication and cooperation between public AES and agricultural producers, but also that it is necessary to make certain modifications in the work of extension officers, in order to be more focused on the needs of farmers, which will ultimately strengthen mutual trust and perception of the extension service as a significant factor in improving agricultural production in Serbia. 


\section{ACKNOWLEDGMENT}

This paper is a part of the research conducted within the contract on the implementation and financing of scientific research work in 2020 between the Faculty of Agriculture in Belgrade and the Ministry of Education, Science and Technological Development of the Republic of Serbia, contract number: 451-03-68/2020-14 and 200116.

\section{REFERENCES}

Al-Zahrani, K. H., Aldosari, F. O., Baig, M. B., Shalaby, M.Y., \& Straquadine, G. S. (2016). Role of Agricultural Extension Service in Creating Decision - Making Environment for the Farmers to Realize Sustainable Agriculture in Al-Qassim and Al-Kharj Regions Saudi Arabia. The Journal of Animal \& Plant Sciences, 26(4), 1063-1071.

Čikić, J., \& Petrović, Ž. (2013). Diffusion of Knowledge and Innovations in Serbian Agriculture. In: D. Škorić, D. Tomić, \& V. Popović (Eds.), Agri-Food Sector in Serbia State and Challenges (pp. 91-118). Belgrade: Serbian Academy of Sciences and Arts, Board for Village - Serbian Association of Agricultural Economics.

Đurić, K., Bulatović, M. L., Marjanović, J., \& Prodanović, R. (2019). Stavovi poljoprivrednika u Republici Srbiji o poljoprivrednoj savetodavnoj službi. In: B. Krstić, S. Jelić, \& Z. Rajić (Eds.), Village and Agriculture (pp. 215-226). Univerzitet Bijeljina.

Idrisa, Y. L, \& Ogunbameru, B.O. (2008). Farmers' assessment of the Unified Agricultural Extension service in Borno State, Nigeria. Journal of Agricultural Extension, 11(1), 106114.

Maoba, S. (2016). Farmers' Perception of Agricultural Extension Service Delivery in Germiston Region, Gauteng Province, South Africa. South African Journal of Agricultural Extension, 44(2), 167-173. http://dx.doi.org/10.17159/24133221/2016/v44n2a415

Nikolić, M., Paunović, T. (2019). Role of Universities in Knowledge and Innovation System in Agriculture in European countries. In: B. Krstić, S. Jelić, \& Z. Rajić (Eds.), Village and Agriculture (pp. 172-183). Bijeljina: Univerzitet Bijeljina.

Norton, G. W., \& Alwang, J. (2020). Changes in Agricultural Extension and Implication for Farmers Adoption of New Practices. Applied Economic Perspectives and Policy, 42(1), 8-20. https://doi.org/10.1002/aepp.13008

Qtaishat, T., \& AL-Sharafat, A. (2012). Attitudes of Vegetable Farmers Towards Public Agricultural Extension Services. American Journal of Agricultural and Biological Sciences, 7(3), 370-377.

Sarker, A., \& Itohara, Y. (2009). Farmers' Perception about the Extension Services and Extension Workers: The Case of Organic Agriculture Extension Program by PROSHIKA. American Journal of Agricultural and Biological Sciences, 4(4), 332-337.

Veselinović, B., \& Drobnjaković, M. (2014). Qualitative and quantitative analysis of micro and macro aspects of agricultural finance. Economics of agriculture, 61(3), 771-787.

Volk, T., Erjavec, E., \& Mortensen, K. (2015). Poljoprivredna politika i evropske integracije u jugoistočnoj Evropi (Agricultural Policy and European Integration in Southeastern Europe). Food and Agriculture Organization of the United Nations by the Regional Rural Development Standing Working Group, Budimpešta.

Zrakić, M., Lončar, H., Išasegi, V., Rukavina, M., \& Žutinić, Đ. (2018). Stavovi poljoprivrednika o inovacijama i ulozi savjetodavne službe u njihovom širenju. Agroeconomia Croatica, 8(1), 64-74. https://doi.org/10.3844/ajabssp.2012.370.377 